\title{
Research on Student Management System in Colleges
}

\author{
TAO Shu \\ Department of computer \\ Wuhan polytechnic \\ Wuhan 430074, China \\ 311703740@qq.com
}

\begin{abstract}
The responsibility of colleges and universities is to train high-quality socialist talents in the new era. Through effective student management, it is particularly important to make students become the pillar of the country. This paper will explore the student management of colleges and universities from three aspects. The regulations on student management of ordinary colleges and universities have very important practical significance in student management of colleges and universities. The relationship between the rights and obligations of students in colleges and universities is of positive significance to the management of students in colleges and universities. The combination of people-oriented thought and student management is a strong complement to the university student management.
\end{abstract}

Keywords-“Student management regulations of ordinary colleges";rights and obligations; the ideology of humanism

\section{INTRODUCTION}

As an important part of China's education system, institutions of higher learning provide technical professionals for the society. In the process of teaching activities in higher vocational colleges, student management is an indispensable component. There are still some problems in the student management of colleges and universities, which will further affect the development of student management in higher vocational colleges. Therefore, in view of the existing problems, colleges and universities should take timely measures to solve the problems based on reflection, so as to better realize the education talent cultivation goal of colleges and universities. This paper mainly discusses the implementation and development of student management in colleges and universities from three dimensions.

\section{PRACTICAL SIGNIFICANCE OF THE REGULATIONS ON STUDENT MANAGEMENT OF ORDINARY COLLEGES AND UNIVERSITIES IN STUDENT MANAGEMENT OF COLLEGES AND UNIVERSITIES}

In February 2017, the newly revised regulations on student management of ordinary colleges and universities were promulgated. In the central committee of the communist party of China governing the country according to law and implement the spirit of the meeting of university ideological and political work under the big background, the common colleges and universities student management stipulation "the promulgation and implementation of the comprehensive administration according to law, the school has an important role, and establish a sound legal system, the construction of student management in colleges and universities has a positive far-reaching influence of the rule of law thought. The rule of law thinking of the management of university students, is based on the rule of law concept of the management of university students, according to the basic requirement of the law, based on the principle of reasonable and legitimate, using legal norms, principles and concepts, undertake to the student education management activity and the concept of the process, is the concentrated reflection of college student management mode of thinking, is also the basis and premise of colleges and universities student management standardized, scientific. Therefore, we should build the rule of law thinking of college student management, effectively promote the use of rule of law thinking in college student management, improve the level of work and improve the quality of talent training.

1. Students' healthy growth cannot be separated from their self-education and management, as well as the restrictions and protection of proprietary laws and regulations. On the one hand, influenced by many factors such as social development, family environment and personal growth, there are still some problems such as weak legal awareness and weak rule awareness in the process of the growth of contemporary young students. They overemphasize personal freedom and rights while ignore their own responsibilities and obligations. On the other hand, in the process of student management, some institutions of higher learning still exist the phenomenon of non-compliance, individual differences and different things, which neglects and damages students' legitimate rights and interests. The implementation of the regulations on student management of ordinary colleges and universities has protected students' legitimate rights and interests and played a role in escorting the growth of students.

2. Basic compliance of strengthening legal construction in institutions of higher learning. The process of legal construction in institutions of higher learning is a unique way of thinking, behavior, rule of law spirit, rule of law awareness, rule of law ability and rule of law system with the students as the subject. How to manage students according to laws and regulations is the most important thing for colleges and universities to strengthen legal construction. The regulations designed to "regulate the behavior of common colleges and universities student management, maintenance of common 
colleges and universities normal education teaching order and living order, and safeguard legitimate rights and interests of students", is to regulate and constraint the behavior of running a school in institutions of higher learning, and behavior norms and constraints to the student, straighten out the relationship between school and students, has been clear about the student's rights and obligations, for colleges and universities to strengthen the construction of the rule of law provides the basic to follow.

\section{THE RELATIONSHIP BETWEEN THE RIGHTS AND OBLIGATIONS OF STUDENTS IN COLLEGES AND UNIVERSITIES}

The relationship between the rights and obligations of students in colleges and universities is related to student management. In the rights-based paradigm. Power comes from power. Power serves right and power should be defined by right. Power must be conditioned by rights. The power of university comes from students' rights and should serve students' rights. The law gives the university the right to manage. But the school has the power of management and even punishment. It is to maintain the normal teaching order. Enable the educatee to engage in related activities under the unified management of the school. The allocation and operation of university power should fully guarantee the realization of students' rights, coordinate the conflicts of students' rights and prevent the mutual infringement of students' rights. Maintain and promote a balance of student rights. University power should be based on student rights. Exercise the right of management and punishment in a just and legal way. All work shall not infringe upon the basic civil rights of students as independent civil subjects. The so-called power of colleges and universities should be restricted by students' rights, reflecting the supervision and control of the exercise of power of colleges and universities. The power of colleges and universities is demonstrated through legislation, and the restraining mechanism is formed through judicial correction and social supervision. In addition, colleges and universities should also pay attention to the transformation of their own educational philosophy and emphasize people-oriented. Pay attention to the organic combination of education, management and service, clarify students' subjective status, and cultivate students' ability of education, self-management and self-service.

\section{THE COMBINATION OF PEOPLE-ORIENTED THOUGHT AND STUDENT MANAGEMENT WORK}

1. The meaning of people-oriented management in schools. The school's people-oriented management is to combine the people-oriented thought with the student management work, from the perspective of caring for students, respecting students' personality, stimulating students' creativity, and making the school management mode people-oriented guiding ideology. Under the guidance of this idea, we should take students as the subject, as far as possible mobilize the human resources in the campus, and serve the students and their internal and external stakeholders, so as to achieve the teaching objectives and cultivate students' talents. The school's people-oriented management includes two aspects :(1) people-oriented and students' physical and mental development. In the process of teaching management, students are the subject. Therefore, students manage in the management work. In the management work, in addition to respecting students' personality and stimulating students' creativity and enthusiasm, the school should also pay attention to developing students' characteristics and shape students' conduct, outlook on life and values. (2) people-orientation should be the guiding ideology in all the teaching work of the school and permeate into all the management. The people-oriented idea is that the school carries forward the student-oriented, relies on the student, for the student's idea, enables the student to experience the democratic, humanistic management way.

2. Existing problems in student management. (1) The backward management concept does not meet the requirements of the new society for students. In the past, the management philosophy usually has a strict hierarchy. The administrators have all the rights to manage the students, and the students must obey the constraints of the administrators. However, it restricts students' physical and mental development, is not conducive to the cultivation of talents, and has a hindering effect on the development of the country and society. (2) The management method is rigid and rigid, and students can't experience humanized service. The methods of student management need to be studied deeply, not simply and crudely. Different management methods will have different effects. In the traditional teaching management work, the lack of mutual communication with students is often simply considered that students are troublemakers and the use of high-pressure policies to control, which will not have a good effect. For example, closed management of students, constraints from all aspects of students' study and life, and the formulation of various punishment regulations. Under such management mode, students' attendance and discipline have made progress on the surface, but it has hindered their all-round development. (3) Management is too single and does not pay attention to the comprehensive development of students. Nowadays, what society demands is the talent with balanced development of knowledge, conduct, physical quality and other aspects. Therefore, the school student management should pay attention to the comprehensive development of students. Students will be developed into a new generation of talent with agile thinking, good conduct, strong body and perseverance.

3. Student management initiatives under the peopleoriented concept. (1) Establish new management concepts. To trust the students, to believe that most students can consciously complete learning tasks, they are an individual, with independent thinking, can distinguish between good and evil. Respect students' reasonable demands and replace punishment with reward system. Stimulate the creativity of students and promote the cultivation of students' personality. (2) Implement humanized management services. For students management should fully to understand students to hear, for violation of JiLvZhe is given priority to with persuasion, psychological consulting agency, to help the student to carry on the psychological help, pay close attention to the students' family situation, difficult students to provide help for the life, pay attention to students after school life, for the feedback from the students attention, accept students reasonable Suggestions, to make the students feel the warmth of the school. (3) Comprehensively develop the quality of students. In the 
process of students' growth, it is far from enough to highlight the scores. It is also important to have good psychological quality and pay attention to the all-round development of students. For example, a party can be held to enhance the friendship between students and improve communication skills. Hold the sports meeting regularly to strengthen the students' physique.

\section{CONCLUSION}

We will implement the regulations on the management of students in institutions of higher learning and strengthen the rule of law and the rule of law for university students. It is of great importance to clarify the relationship between the rights and obligations of the students in colleges and universities. The combination of people-oriented and student management is advancing with The Times. As a talent training base, the school should pay more attention to people-oriented. As long as the above three points are paid attention to and implemented, the student management in colleges and universities will have rules to follow and laws to be followed, so as to cultivate highquality successors of socialism in the new era.

\section{REFERENCES}

[1] XU Xiao-ling,HE Dong-ping.The protection of students' rights under the legalization of college student management -- taking students' individual rights as the main perspective[J].Journal of anhui agricultural university: social sciences, 2012 (1)

[2] FU Ling.Study on the legalization of student management in colleges and universities[J].Journal of chifeng college: nature, 2016 (17)

[3] YIN Xiao_min.Legal thinking on constructing harmonious university campus -- based on the harmonious relationship between university and students[J].Modern education science, 2006 (3).

[4] LAO Kai-sheng.China education legal review[M].Beijing.Science and Education Press.2003.11.

[5] WEI Xiao-lan.A brief analysis of the conflict and balance between university management and student education[J].Zhengzhou university. 2007 